\title{
Do Aqua Regia and EPA 3051A methods underestimate the pseudo-total $P$ content in clay soil fraction?
}

\author{
Os métodos Água Regia e EPA 3051A subestimam o teor pseudo-total de \\ P na fração argila do solo?
}

\author{
Vander Freitas Melo* [D, Lauriane Guidolin Guedes' \\ 'Universidade Federal do Paraná/UFPR, Departamento de Solos e Engenharia Agrícola, Curitiba, PR, Brasil \\ *Corresponding author: melovander@yahoo.com.br \\ Received in June 3, 2020 and approved in August 31, 2020
}

\begin{abstract}
It is common the use of $3051 \mathrm{~A}$ and aqua regia methods to assess the pseudo-total and total P contents in soil and in its fractions. However, previous study has shown the formation of large amounts of short-range order materials (SRO) in the residues of these extractions. The objective of this work was to evaluate whether phosphate resorb in the SRO formed in the residue of 3051A and aqua regia extractions in clay soil fraction. Residues obtained from the $3051 \mathrm{~A}$ and aqua regia were recovered from filter papers. To characterize the SRO in these residues, sequential extractions were performed with $0.2 \mathrm{~mol} \mathrm{~L}^{-1}$ ammonium oxalate and $0.5 \mathrm{~mol} \mathrm{~L}^{-1} \mathrm{NaOH}$. The maximum pseudo-total $\mathrm{P}$ content extracted by aqua regia was $6800 \mathrm{mg} \mathrm{kg}^{-1}$. If SRO formed during this acid extraction was not extracted, $698 \mathrm{mg} \mathrm{kg}^{-1} \mathrm{P}$ would have been not accounted (underestimation of $10.3 \%$ ). This high level of $P$ resorption in the $3051 \mathrm{~A}$ and aqua regia extraction lead to misinterpretations of P reserve in clay fraction. Phosphate resorption was mainly in SRO extracted by ammonium oxalate for both $3051 \mathrm{~A}$ and aqua regia residues. The chemical environment of the 3051 A and aqua regia extractions facilitated the inner sphere adsorption of $\mathrm{H}_{2} \mathrm{PO}_{4}^{-}$in ferrol and aluminol groups of the SRO- ammonium oxalate. There was larger resorption of $\mathrm{H}_{2} \mathrm{PO}_{4}^{-}$in the $3051 \mathrm{~A}-\mathrm{NaOH}$ in relation to $\mathrm{NaOH}$ - aqua regia.
\end{abstract}

Index terms: Short-range order materials; inner sphere adsorption; isomorphic substitution; sequential extractions.

\begin{abstract}
RESUMO
É comum o uso dos métodos 3051A e água régia para avaliar o teor pseudo-total e total de P nos solos e em suas frações. No entanto, estudo anterior mostrou a formação de grandes quantidades de materiais de baixa ordem estrutural (MBOE) nos resíduos dessas extrações. O objetivo deste trabalho foi avaliar se ocorre readsorção de fosfato no MBOE dos resíduos das extrações 3051A e água régia na fração argila de solos. Os resíduos obtidos a partir do 3051A e água régia foram recuperados dos papéis de filtro. Para caracterizar o MBOE nesses resíduos foram realizadas extrações sequenciais com oxalato de amônio $0,2 \mathrm{~mol} \mathrm{~L}^{-1} \mathrm{e} \mathrm{NaOH} 0,5 \mathrm{~mol} \mathrm{~L}^{-1}$. O teor máximo de $\mathrm{P}$ pseudo-total extraído pela água régia foi de $6800 \mathrm{mg} \mathrm{kg}^{-1}$. Se o MBOE formado durante a água régia não fosse extraída nesta amostra, $698 \mathrm{mg} \mathrm{kg}^{-1}$ de P não seriam contabilizados (subestimação de 10,3\%). Esse alto nível de readsorção de P na extração 3051 A e água régia leva a interpretações equivocadas da reserva de nutrientes na fração argila. A readsorção de fosfato foi principalmente no MBOE extraído pelo oxalato de amônio nos resíduos 3051A e água régia. O ambiente químico das extrações 3051A e água régia facilitou a readsorção por esfera interna de $\mathrm{H}_{2} \mathrm{PO}_{4}^{-}$nos grupos ferrol e aluminol do MOBE-oxalato de amônio. Houve maior reabsorção de $\mathrm{H}_{2} \mathrm{PO}_{4}^{-}{ }^{-} \mathrm{no} 3051 \mathrm{~A}-\mathrm{NaOH}$ em relação ao $\mathrm{NaOH}$-água régia .
\end{abstract}

Termos para indexação: Materiais de baixa ordem estrutural; adsorção por esfera interna; substituição isomórfica; extrações sequenciais.

\section{INTRODUCTION}

EPA 3051A is the most used method to determine the pseudo-total content of elements in soils with environmental interesse (Chen et al., 1991; Dudka; Markert, 1992; Salonen; Korkka-Niemi, 2007; Souza et al., 2015; Melo et al., 2017). EPA 3051A involves digestion in a closed microwave oven system with concentrated
$\mathrm{HNO}_{3}$ and $\mathrm{HCl}(3: 1)$ or only concentrated $\mathrm{HNO}_{3}$ (United State Environment Agency - USEPA, 1998). Aqua regia is another methodology frequently used to extract pseudo-total contents of heavy metals in soils (Öztam; Düring 2012). Normally, this method involves digestion in an open system (Sastre et al., 2002) and uses the same concentrated acids specified by EPA 3051A; however, 
the aqua regia method uses the inverse ratio of the acid volumes: $\mathrm{HCl} / \mathrm{HNO}_{3}=3: 1$. It is common the use of $3051 \mathrm{~A}$ and aqua regia aqua regia methods to assess the pseudo-total and total $\mathrm{P}$ contents in soils (Crosland et al., 1995; Eriksson, Gustafsson; Hesterberg, 2015; Zárubová et al., 2015; Eriksson et al., 2016; Melo et al., 2016). The difference between pseudo-total (aqua regia and EPA 3051A) and total (EPA 3052A) extractions is the use of HF in total extraction for total removal of silicate minerals, such as 2: 1 and 1: 1 (phyllosilicate) and quartz and feldspar (tectosilicate) (USEPA, 1998; Melo et al., 2016). However, due to the low association of interest elements ( $\mathrm{P}$ and heavy metals) with silicate minerals, some authors have found equivalent extractions between EPA 3051A and EPA 3052A (Link et al. 1998; Silva; Nascimento; Biondi, 2013). Even if there was adsorption by internal-sphere of $\mathrm{P}$ in the aluminol groups of the $2: 1$ and 1: 1 secondary minerals, the previous work by Melo et al. (2016) showed that extractions with aqua regia and EPA 3051A dissolve the outermost layers and the total dissolution of thinner, smaller and lower crystallinity kaolinite particles. The aqua regia and EPA 3051 methods completely dissolve relatively stable secondary oxide minerals, such as, gibbsite, goethite and hematite (Melo et al., 2016). Therefore, only unexpected forms of $P$ within the crystalline network of silicate minerals would not be extracted by aqua regia and EPA 3051A. For all these reasons, in the present study, P solubilized by extractions with aqua regia and EPA 3051A was also treated as total. Questions about the accuracy of the EPA 3051A and aqua regia arose from the data of Melo et al. (2016) and Guedes, Melo and Batista (2020). These authors recovered solid residues from the filter papers obtained by using the 3051A and aqua regia methods and identified large contents of low-crystallinity materials (short-range order material - SRO) formed in these residues. As SRO are very reactive, heavy metal resorption were intense, leading to the underestimation of these elements (Guedes; Melo; Batista, 2020). SRO has a high specific surface area and pH-dependent charges (Mendonça et al., 2013). They expose large number of reactive groups, especially silanol $(-\mathrm{SiOH})$, ferrol $(-\mathrm{FeOH})$, and aluminol (-AlOH) (Theng et al., 1982; Mendonça et al., 2013).

Three alternative methods have been commonly used to estimate the total P (Leytem; Kpomblekou, 2009): sodium carbonate $\left(\mathrm{Na}_{2} \mathrm{CO}_{3}\right)$ fusion, perchloric acid $\left(\mathrm{HClO}_{4}\right)$ digestion, and sodium hypobromite $(\mathrm{NaOBr})$ oxidation followed by $\mathrm{H}_{2} \mathrm{SO}_{4}$ dissolution. These three methods convert soil organic $\mathrm{P}$ to inorganic $\mathrm{P}$ to allow total $\mathrm{P}$ determination. the $\mathrm{Na}_{2} \mathrm{CO}_{3}$ fusion is thought to give more reliable results (Sommers; Nelson, 1972). However, complementary studies with these methods should be done to check the percentage of $P$ recovery in relation to the EPA 3052 method and if there is no SRO formation in the residues of these extractions.

The hypothesis of the present study is that the resorption of $\mathrm{P}$ will also occurs, as phosphate compost has high affinity for $-\mathrm{AlOH}$ and $-\mathrm{FeOH}$. groups (Satti et al., 2007; Havlin et al., 2009).

The objective of this work was to evaluate whether phosphate resorb in the SRO formed in the residue of 3051 A and aqua regia extractions in clay soil fraction.

\section{MATERIAL AND METHODS}

\section{Soil sampling}

Soil samples were collected in two different sites in Adrianópolis municipality, Paraná State, Southern Brazil (Table 1). Each site has a distinct parent material. Another two soil profiles were selected from São José dos Pinhais and from Londrina, both municipalities also belong to Paraná State, Southern Brazil (Table 1).

Soils with different clay mineralogy were selected (Melo et al., 2016; Guedes; Melo; Batista, 2020): Adrianópolis/site 1 - soils with high smectite contents; Adrianópolis/site 2 - soils with varying contents of smectite and kaolinite; São José dos Pinhais/Inceptsol - soil with high contents of kaolinite; and Londrina/ Oxisol - soil with high contents of Fe (hematite) and $\mathrm{Al}$ (gibbsite) oxides. All soil samples were also used in the heavy metal's resorption study of Guedes, Melo and Batista (2020), where X-ray diffraction clay patterns of each representative group of soil are presented.

To avoid interference from the minerals of the sand and silt fractions (mainly quartz and magnetite), only the clay fraction was used to study the dissolution of secondary minerals by Aqua Regia and 3051A and the formation of SRO with the elements released from these dissolutions.

\section{Separation of soil fractions}

Approximately $20 \mathrm{~g}$ of air-dry fine earth (three replicates) was mixed with $\mathrm{H}_{2} \mathrm{O}_{2} 30 \%$ (v/v) in a water bath at $70{ }^{\circ} \mathrm{C}$ until the end of reaction. After removing the organic matter, the samples were dispersed in a $100 \mathrm{~mL}$ of 0.2 $\mathrm{mol} \mathrm{L}{ }^{-1} \mathrm{NaOH}$. The sand fraction was retained in a 0.053 $\mathrm{mm}$ mesh sieve, and the silt and clay fractions were separated by a sedimentation method according to Stokes' Law (Gee; Bauder, 1986). The clay fraction was dried in an oven at $40{ }^{\circ} \mathrm{C}$ for $48 \mathrm{~h}$, ground, and passed through a $0.2 \mathrm{~mm}$-mesh sieve. 
Table 1: Location and some properties of the soils.

\begin{tabular}{|c|c|c|c|c|c|}
\hline Sample & Profile & $\begin{array}{l}\text { Sampling depth } \\
\mathrm{cm}\end{array}$ & \multicolumn{2}{|c|}{$\begin{array}{l}\text { Geography } \\
\text { coordinates }\end{array}$} & $\begin{array}{l}\text { Clay } \\
\text { g kg-1 }^{-1}\end{array}$ \\
\hline \multicolumn{6}{|c|}{ Adrianópolis - Site 1 (Neossolo/Entisol - Calcite marble) } \\
\hline 1 & 1 & $0-15$ & \multirow{2}{*}{$24^{\circ} 40^{\prime} 57^{\prime \prime} \mathrm{S}$} & \multirow{2}{*}{$48^{\circ} 55^{\prime} 06^{\prime \prime} \mathrm{W}$} & 470 \\
\hline 2 & 1 & $15-25$ & & & 440 \\
\hline 3 & 2 & $0-15$ & \multirow{2}{*}{$24^{\circ} 40^{\prime} 58^{\prime \prime} \mathrm{S}$} & \multirow{2}{*}{$48^{\circ} 55^{\prime} 04^{\prime \prime} \mathrm{W}$} & 310 \\
\hline 4 & 2 & $15-25$ & & & 360 \\
\hline 5 & 3 & $0-15$ & \multirow{2}{*}{$24^{\circ} 40^{\prime} 58^{\prime \prime} \mathrm{S}$} & \multirow{2}{*}{$48^{\circ} 55^{\prime} 07^{\prime \prime} \mathrm{W}$} & 250 \\
\hline 6 & 3 & $15-30$ & & & 300 \\
\hline \multicolumn{6}{|c|}{ Adrianópolis - Site 2 (phyllite-mica schist) } \\
\hline 7 & 4 & $0-10$ & $24^{\circ} 50^{\prime} 20^{\prime \prime S}$ & $49^{\circ} 00^{\prime} 11 " \mathrm{~W}$ & 300 \\
\hline 8 & 5 & $0-10$ & $24^{\circ} 50^{\prime} 20^{\prime \prime S}$ & $49^{\circ} 00^{\prime} 11 " \mathrm{~W}$ & 270 \\
\hline 9 & 6 & $0-10$ & $24^{\circ} 50^{\prime} 19^{\prime \prime S}$ & $49^{\circ} 00^{\prime} 11 " \mathrm{~W}$ & 200 \\
\hline 10 & 7 & $0-10$ & $24^{\circ} 50^{\prime} 18^{\prime \prime S}$ & $49^{\circ} 00^{\prime} 12^{\prime \prime} \mathrm{W}$ & 300 \\
\hline 11 & 8 & $0-10$ & $24^{\circ} 50^{\prime} 18^{\prime \prime S}$ & $49^{\circ} 00^{\prime} 12^{\prime \prime W}$ & 270 \\
\hline \multicolumn{6}{|c|}{ Londrina (Latossolo/Oxisol - basalt) } \\
\hline 12 & 9 & $15-95$ & $23^{\circ} 23^{\prime} 30^{\prime \prime} \mathrm{S}$ & $51^{\circ} 11^{\prime} 05^{\prime \prime} \mathrm{W}$ & 831 \\
\hline \multicolumn{6}{|c|}{ São José dos Pinhais (Cambissolo/Inceptsol - granite/gneiss) } \\
\hline 13 & 10 & $30-60$ & $25^{\circ} 35^{\prime} 32^{\prime \prime} \mathrm{S}$ & $49^{\circ} 03^{\prime} 47^{\prime \prime W}$ & 446 \\
\hline
\end{tabular}

Source: modified from Guedes, Melo and Batista (2020).

\section{Extraction of $\mathrm{P}$ pseudo-total with aqua regia}

Approximately $0.5 \mathrm{~g}$ of clay (triplicate) was weighed in glass digestion tubes (Berrow; Stein, 1983). After adding $1.0 \mathrm{~mL}$ of concentrated $\mathrm{HNO}_{3}$, the tubes were maintained in a block digester for $15 \mathrm{~min}$ at $110^{\circ} \mathrm{C}$. The content of $\mathrm{P}$ was determined by inductively coupled plasma optical emission spectroscopy (Varian 720-ES) (ICP-OES). The operational conditions of the ICP-OES with an axial configuration were: radiofrequency power $-1200 \mathrm{~W}$; replicate -3 ; plasma gas flow rate $-15 \mathrm{~L}$ $\min ^{-1}$; auxiliary gas flow rate $-1.5 \mathrm{~L} \mathrm{~min}^{-1}$; sample uptake rate $-1.0 \mathrm{~mL} \mathrm{~min}^{-1}$; nebulizer gas flow rate $-0.5 \mathrm{~L} \mathrm{~min}^{-1}$; nebulizer type - spray chamber; spray chamber - doble spray; injector tube diameter -1.2 $\mathrm{mm}$; signal integration time $-15 \mathrm{~s}$; wavelength -203 $\mathrm{nm}$. All procedures were performed including the blank analytical solutions.

All reagents used were of analytical grade and purity and all solutions were prepared using ultra-pure water $\left(18 \mathrm{~m} \Omega \mathrm{cm}^{-1}\right.$, Milli-Q, Milipore).

\section{Extraction of P pseudo-total with EPA 3051A}

Approximately $0.5 \mathrm{~g}$ of clay (triplicates) was transferred to Teflon tubes in the presence of $9 \mathrm{~mL}$ of concentrated $\mathrm{HNO}_{3}$ and $3 \mathrm{~mL}$ of concentrated $\mathrm{HCl}$ (USEPA, 1998). The tubes were sealed and maintained in a microwave oven (MARS Xpress 6, CEM) for $8 \mathrm{~min}$ and $40 \mathrm{~s}$ to increase the temperature to $175^{\circ} \mathrm{C}$. This temperature was maintained for an additional period of $4 \mathrm{~min}$ and $30 \mathrm{~s}$. The content of $\mathrm{P}$ was determined by ICP-OES.

\section{Recovery of residues of the aqua regia and EPA 3051A extractions}

The extraction residues of aqua regia and EPA 3051A residues were recovered from quantitative filter paper (Macherey $\mathrm{Nagel}^{\circledR}$ ) in previously tared plastic containers using ultrapure water $\left(18.2 \mathrm{M} \Omega \mathrm{cm}\right.$ at $\left.25^{\circ} \mathrm{C}\right)$ jets. The residues were dried in an oven at $40^{\circ} \mathrm{C}$ for $48 \mathrm{~h}$ and weighed to calculate the percentage of material removed by the aqua regia and EPA3051A digestions. 


\section{Sequential extractions of short-range order material} (SRO) in the residues of the aqua regia and 3051A

To produce sufficient amount of residues, the extractions with aqua regia and 3051A were repeated 10 times each.

\section{Ammonium Oxalate extraction}

Approximately $0.5 \mathrm{~g}$ (triplicate) of the EPA $3051 \mathrm{~A}$ and aqua regia residues were placed in centrifuge tubes. After adding $12.5 \mathrm{~mL}$ of the $0.2 \mathrm{~mol} \mathrm{~L}^{-1} \mathrm{pH} 3.0$ ammonium oxalate, the tubes were agitated for $2 \mathrm{~h}$ in a horizontal shaker at $100 \mathrm{rpm}$ (Jackson; Lim; Zelazny, 1986). The suspension was centrifuged at $5000 \mathrm{rpm}$, and the supernatant was collected to determine the P content by ICP-OES. The residue was washed twice with $30 \mathrm{~mL}$ of $0.5 \mathrm{~mol} \mathrm{~L}^{-1}\left(\mathrm{NH}_{4}\right)_{2} \mathrm{CO}_{3}$ and washed once with $30 \mathrm{~mL}$ of ultrapure water to remove the excess salts from the ammonium oxalate solution. The samples were dried in an oven at $40{ }^{\circ} \mathrm{C}$ for $48 \mathrm{~h}$ and weighed.

\section{$\mathrm{NaOH}$ extraction}

Approximately $0.3 \mathrm{~g}$ (triplicate) of the ammonium oxalate residue was homogenized with $30 \mathrm{~mL}$ of $0.5 \mathrm{~mol}$ $\mathrm{L}^{-1} \mathrm{NaOH}$. The suspension was heated at $90{ }^{\circ} \mathrm{C}$ for 30 min in a water bath, centrifuged at $5000 \mathrm{rpm}$, and the supernatant was collected to determine the content of $\mathrm{P}$ by ICP-OES.

\section{RESULTS AND DISCUSSION}

Melo et al. (2016) and Guedes, Melo and Batista (2020) used the same samples as the present study and the data from these authors certify the formation of SRO after extractions with Aqua Regia and 3051A. These authors used the techniques of X-ray diffraction (formation of diffuse reflections) (Figure 1) and transmission electron microscopy to identify the SRO. Quantity and chemical composition of short-range order material (SRO) formed during 3051A and aqua regia extractions were detailed by Guedes, Melo and Batista (2020), and some important findings can be highlights: i) the amount and composition of SRO was dependent of clay mineralogy. The residue of 3051 A and aqua regia extractions were composed by almost $100 \%$ of SRO in the smectitic samples (Adrianópolis/site - samples 1 to 6); ii) chemical composition of SRO of aqua regia and 3051A residues: ammonium oxalate extracted mainly $\mathrm{Al}_{2} \mathrm{O}_{3}$ and $\mathrm{Fe}_{2} \mathrm{O}_{3}$ and the SRO solubilized by $\mathrm{NaOH}$ are composed of $\mathrm{SiO}_{2}$ and residual amount of $\mathrm{Al}_{2} \mathrm{O}_{3}$. Ammonium oxalate has the ability to dissolve allophane, imogolite, and low crystallinity Fe (ferrihydrite, fougerite and schwertmannite), $\mathrm{Al}$ and $\mathrm{Mn}$ oxides (Singh; Gilkes, 1991; Jackson; Lim; Zelazny, 1986). The sequential extraction with $0.5 \mathrm{~mol} \mathrm{~L}^{-1} \mathrm{NaOH}$ dissolved mainly lowcrystallinity Si-O (opaline silica) layers that were resistant to prior extraction with ammonium oxalate (Guedes; Melo; Batista, 2020).

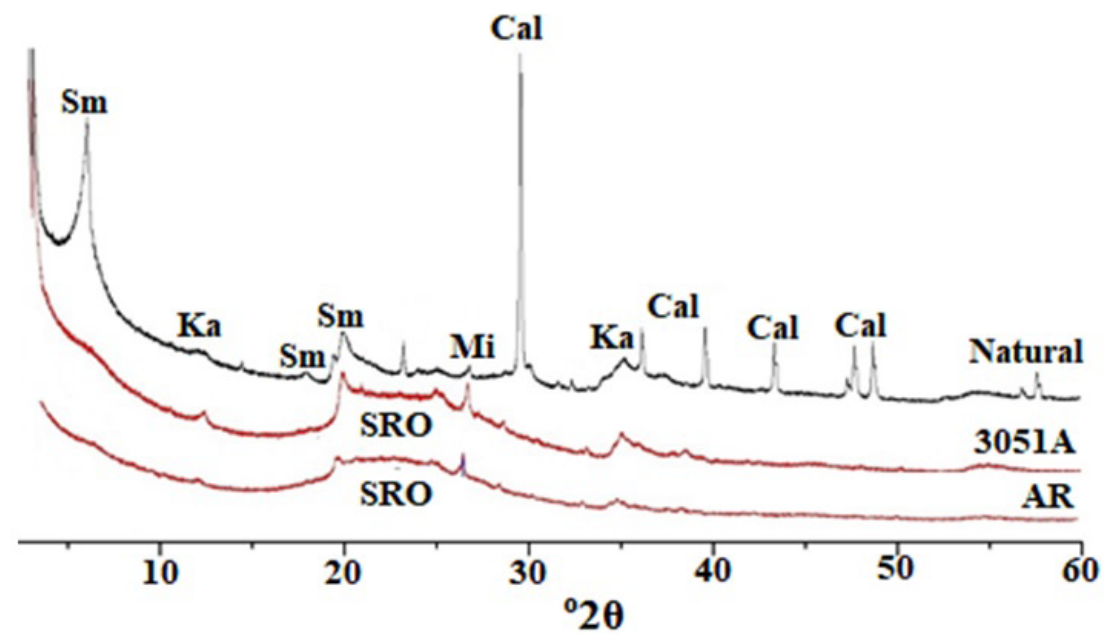

Figure 1: X-ray diffraction (Cu-Ka radiation) of natural clay and after extraction by EPA 3051A and aqua regia (AR) of the sample 5. Sm: smectite, Ka: kaolinite, Cal: Calcite, Mi: Mica, SRO: short-range order phase.

Source: Adapted from Guedes, Melo and Batista (2020). 
The broad term 'resorption' was used in the present manuscript to represent all P-solid phase interactions: precipitation, complexation, adsorption by the outer sphere, adsorption by the inner sphere and the introduction of heavy metals in the SRO structure by isomorphic substitution. The maximum pseudo-total $\mathrm{P}$ content extracted by aqua regia was in the sample 6 (6800 $\left.\mathrm{mg} \mathrm{kg}^{-1}\right)$ (Figure 2a). If SRO was not extracted after aqua regia in this sample, $698 \mathrm{mg} \mathrm{kg}^{-1}$ of $\mathrm{P}$ would have been not assembled (underestimation of 10.3 $\%$ in relation of aqua regia pseud-total content) (Figures $2 \mathrm{~b}, \mathrm{c}$ ). The maximum percentage of $\mathrm{P}$ resorption in the SRO was in the $3051 \mathrm{~A}$ residue in sample 7 (underestimation of $36 \%$ in relation of 3051A pseudo-total content) (Figure 2b). This level of $\mathrm{P}$ resorption leads to misinterpretations of nutrient reserve in soils.

P resorption was mainly in SRO-ammonium oxalate for both 3051A and aqua regia residues (Figure 2). In the
Oxisol (sample 12), $100 \%$ of P-SRO (76 mg kg-1 or $19 \%$ ) was released by solubilization of the aqua regia residue by ammonium oxalate. The mixture of concentrated $\mathrm{HCl}$ and concentrated $\mathrm{HNO}_{3}$ used for pseudo-total digestion reduces the $\mathrm{pH}$ of the soil/reagent mixture to below 1.0 (Guedes; Melo; Batista, 2020). In this $\mathrm{pH}$ range, protonation and the following charge distribution occur in the aluminol, ferrol and silanol reactive groups on the surface of the SRO: $-\mathrm{AlOH}_{2}^{+0.5} ;-\mathrm{FeOH}_{2}^{+0.5} ;-\mathrm{SiOH}^{0}$ (Poggere et al., 2016). Oxyanion specific adsorption $\left(\mathrm{H}_{3} \mathrm{PO}_{4}{ }^{\circ}\right)$ in ferrol and aluminol groups is favored when these radicals are at the maximum protonation $\left(\mathrm{OH}_{2}\right)$, as this configuration weakens the metal-oxygen bond, which favors the exchange of ligands and the water molecule output (Equations 1 and 2). The ferrol group is present in SRO-ammonium oxalate and aluminol in SRO- ammonium oxalate and SRO-NaOH (Guedes; Melo; Batista, 2020). a)

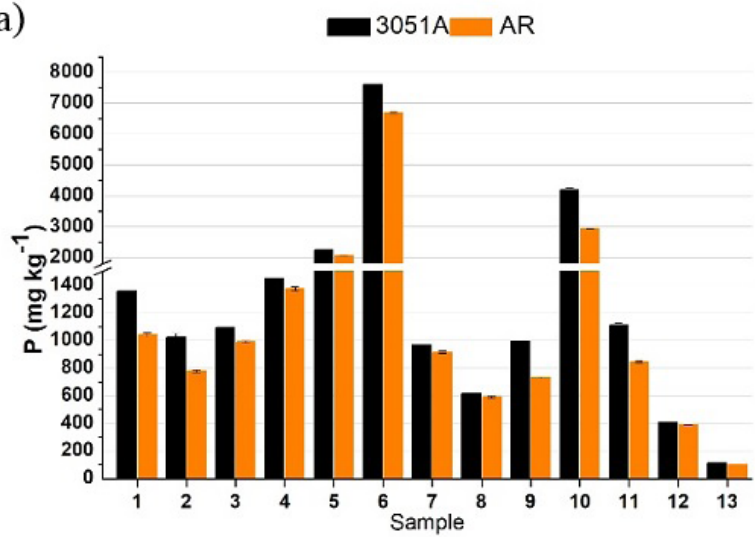

c)

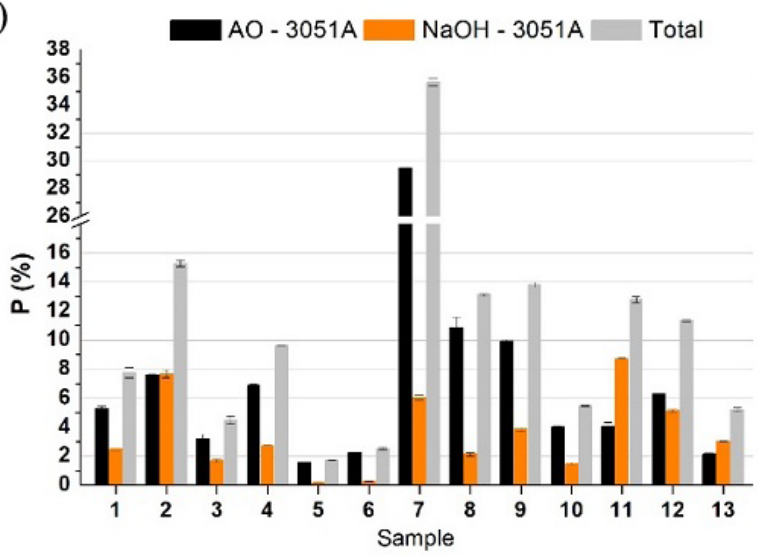

b)

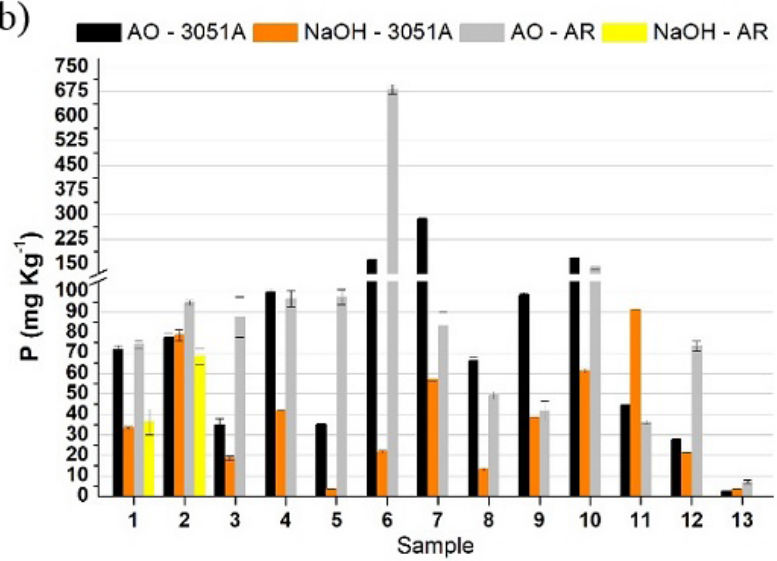

d)

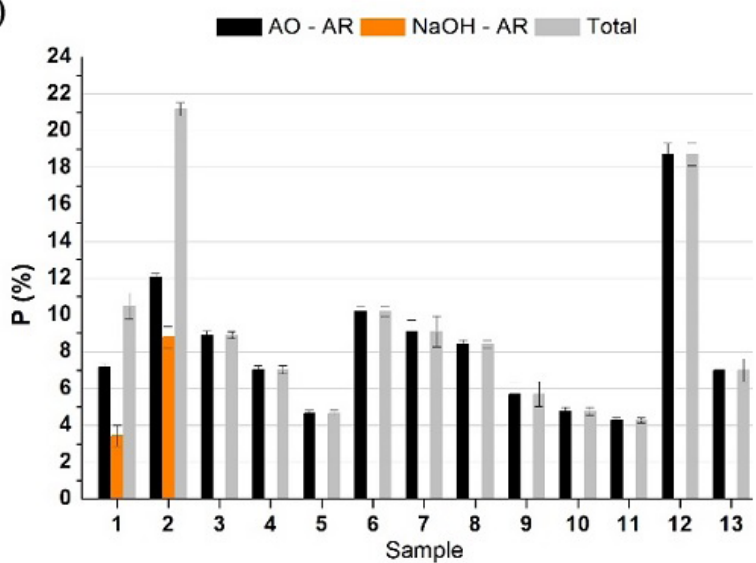

Figure 2: $P$ contents of the extracts of the 3051A and aqua regia (AR) (a), $P$ contents of sequential extractions with ammonium oxalate (OA) and $\mathrm{NaOH}$ in residues of 3051 A and aqua regia (b), and the relative percentages of the contents of these oxides extracted by the sequential extractions with ammonium oxalate and $\mathrm{NaOH}$ in relation to the contents extracted from the 3051A (c) and aqua regia (d). Total = content of the P-ammonium oxalate $+\mathrm{P}-\mathrm{NaOH}$. 
$-\mathrm{AlOH}_{2}^{+0,5}+\mathrm{H}_{3} \mathrm{PO}_{4}{ }^{0} \rightarrow-\mathrm{AlOH}_{3} \mathrm{PO}_{4}^{+0,5}+\mathrm{H}_{2} \mathrm{O}$

$-\mathrm{FeOH}_{2}{ }^{+0,5}+\mathrm{H}_{3} \mathrm{PO}_{4}{ }^{0} \rightarrow-\mathrm{FeOH}_{3} \mathrm{PO}_{4}^{+0,5}+\mathrm{H}_{2} \mathrm{O}$

The predominant form of phosphate is $\mathrm{H}_{3} \mathrm{PO}_{4}{ }^{0}$ below 2.0 (Lindsay, 1979). Although aluminol and ferrol groups of $\mathrm{SRO}$ are positive in this $\mathrm{pH}$ range (Equations 1 and 2), the absence of negative charges on the oxy-anion prevents non-specific adsorption (electrostatic attraction) of the $\mathrm{H}_{3} \mathrm{PO}_{4}{ }^{0}$. It is not also possible the $\mathrm{P}$ input into the SRO-OA structure by isomorphic substitution (IS), because the coordination between $\mathrm{Al}$ and $\mathrm{Fe}$ (octahedral) and $\mathrm{P}$ (tetrahedral) are different.

Digestion of the smectitic samples from Adrianópolis site 1 by $3051 \mathrm{~A}$ released more $\mathrm{SiO}_{2}$ and there was an intense formation of SRO-NaOH (Guedes; Melo; Batista, 2020); however, in this group of samples there is the lowest percentage of $\mathrm{P}$ resorption (Figure 2c, d). The largest contribution of $\mathrm{P}$ in the residues of $3051 \mathrm{~A}$ in relation to aqua regia by the extraction of $\mathrm{SRO}$ with $\mathrm{NaOH}$ is clear. There was a greater formation of Si-tetrahedron layers, since loss of $\mathrm{Si}$ by volatilization is prevented in the 3051A closed system (Guedes; Melo; Batista, 2020). In the open aqua regia system $\left(110^{\circ} \mathrm{C}\right)$, occur intense loss of $\mathrm{Si}$ in the form of volatile compounds (Melo et al., 2016). Taking sample 6 as an example of site 1 of Adrianópolis (Guedes; Melo; Batista, 2020): $\mathrm{SiO}_{2}-\mathrm{NaOH}$ in the aqua regia residue $=4.3 \mathrm{~g} \mathrm{~kg}^{-1} ; \mathrm{SiO}_{2}-\mathrm{NaOH}$ in the $3051 \mathrm{~A}$ residue $=615$ $\mathrm{g} \mathrm{kg}^{-1}$. The phosphate group is formed by four oxygen surrounding the central $\mathrm{P}$ (tetrahedral coordination). The same coordination facilitated the IS of Si tetrahedron by $\mathrm{P}$ tetrahedron in the $\mathrm{SRO}-\mathrm{NaOH}$ of the $3051 \mathrm{~A}$ residue $\left(\mathrm{P}^{5+}\right.$ ionic radius $(0.035 \mathrm{~nm})$ is very close to $\mathrm{Si}^{4+}$ ionic radius $(0.039 \mathrm{~nm}))$. Even under room temperature and pressure, the IS of Si by P is favored, as the theoretical limit of the ionic radius difference necessary to enable IS is $35 \%$ (Zanardo; Marques, 2009). The high pressure of method 3051A increased the IS of Si for P in the SRO-NaOH.

\section{CONCLUSIONS}

The chemical environment of the 3051A and aqua regia extractions facilitated the specific adsorption of $\mathrm{H}_{3} \mathrm{PO}_{4}{ }^{0}$ in ferrol and aluminol groups of the SROammonium oxalate. Phosphate resorption was mainly in SRO extracted by ammonium oxalate for both 3051A and aqua regia residues. There was larger resorption of $\mathrm{H}_{3} \mathrm{PO}_{4}^{0}$ in the $3051 \mathrm{~A}-\mathrm{NaOH}$ in relation to $\mathrm{NaOH}$-aqua regia. The maximum pseudo-total $\mathrm{P}$ content extracted in our sample by aqua regia was $6800 \mathrm{mg} \mathrm{kg}^{-1}$. If short-range order (SRO) formed during this acid extraction was not extracted in this sample, $698 \mathrm{mg} \mathrm{kg}^{-1} \mathrm{P}$ would have been not accounted (underestimation of $10.3 \%$ ). This high level of $\mathrm{P}$ resorption in the $3051 \mathrm{~A}$ and aqua regia extraction leads to misinterpretations of $\mathrm{P}$ reserve in clay fraction.

\section{REFERENCES}

BERROW, M. L.; STEIN, W. M. Extraction of metals from soils and sewage sludges by refluxing with aqua regia. Analyst, 108:277-285, 1983.

CHEN, J. et al. Background concentrations of elements in soils of China. Water, Air, and Soil Pollution, 57-58:699-712, 1991.

CROSLAND, A. R. et al. Comparison of Aqua regia digestion with sodium carbonate fusion for the determination of total phosphorus in soils by inductively coupled plasma atomic emission spectroscopy (ICP). Communications in Soil Science and Plant Analysis, 26(9-10):1357-1368, 1995.

DUDKA, S.; MARKET, B. Baseline concentrations of As, Ba, Be, $\mathrm{Li}, \mathrm{Nb}, \mathrm{Sr}$ and $\mathrm{V}$ in surface soils of Poland. Science of The Total Environment, 122(3):279-290, 1992.

ERIKSSON, A. K. et al. Evolution of phosphorus speciation with depth in an agricultural soil profile. Geoderma, 280:29-37, 2016.

ERIKSSON, A. K.; GUSTAFSSON, J. P.; HESTERBERG, D. Phosphorus speciation of clay fractions from long-term fertility experiments in Sweden. Geoderma, 241-242:6874, 2015.

GEE, G. W.; BAUDER, J. W. Particle-size analysis. In: KLUTE, A. Methods of soil analysis. Part 1: Physical and mineralogical methods. Madison: American Society of Agronomy, p.383-412, 1986.

GUEDES, L. G.; MELO, V. F.; BATISTA, A. H. The classic aqua regia and EPA 3051 a methods can mislead environmental assessments and certifications: Potentially harmful elements resorption in short-range order materials. Chemosphere, 251:126356, 2020.

HAVLIN, J. L. et al. Soil fertility and fertilizers: An introduction to nutrient management. New Delhi: PHI Learning Pvt. Ltd, 2009. 528p.

JACKSON, M. L.; LIM, C. H.; ZELAZNY, L.W. Oxides, hydroxides, and aluminosilicates. In: KLUTE, A. Methods of soil analysis. Part 1: Physical and mineralogical methods. Madison: American Society of Agronomy, p.101-150, 1986. 
LEYTEM, A.; KPOMBLEKOU, K. Total phosphorus in soil. In: KOVAR, J. L.; PIERZYNSKI, G. M. Methods of phosphorus analysis for soils, sediments, residuals, and waters. Second edition. Virginia: Virginia Tech University, p.4449, 2009.

LINK, D.; WALTER, P. J.; KINGSTON, H. M. Development and validation of the new EPA microwave-assisted leach method 3051A. Environmental Science \& Technology, 32(22):3628-3632, 1998.

MELO, V. F. et al. Relationship between heavy metals and minerals extracted from soil clay by standard and novel acid extraction procedures. Environmental Monitoring and Assessment, 188(12):668, 2016.

MELO, V. F. et al. Reference values for potentially harmful elements in soils from Atlantic Rainforest, Brazil. Journal of Geochemical Exploration, 181:138-147, 2017.

MENDONÇA, T. et al. Lead adsorption on clay fraction of two soil profiles of Fields Peninsula, King George Island. Antarctic Science, 25(3):389-396, 2013.

ÖZTAM, S.; DÜRING, R. A. Microwave assisted EDTA extractiondetermination of pseudo total contents of distinct trace elements in solid environmental matrices. Talanta, 99:594602, 2012.

POGGERE, G. C. et al. Adsorption of arsenate $\left(\mathrm{HAsO}_{4}{ }^{2-}\right)$ by the clay fraction of soils of the Keller and Barton Peninsulas, King George Island, Maritime Antarctic. Revista Ciência Agronômica, 48(1):13-21, 2016.

SALONEN, V.; KORKKA-NIEMI, K. Influence of parent sediments on the concentration of heavy metals in urban and suburban soils in Turku, Finland. Applied Geochemistry, 22(5):906-918, 2007.

SASTRE, J. et al. Determination of $\mathrm{Cd}, \mathrm{Cu}, \mathrm{Pb}$ and $\mathrm{Zn}$ in environmental samples: Microwave-assisted total digestion versus aqua regia and nitric acid extraction. Analytica Chimica Acta, 462(1):56-72, 200.
SATTI, P. et al. Factors affecting soil P dynamics in temperate volcanic soils of southern Argentina. Geoderma, 139(12):229-240, 2007.

SILVA, Y. J. A. B.; NASCIMENTO, C. W. A.; BIONDI. C. M. Comparison of USEPA digestion methods to heavy metals in soil samples. Environmental Monitoring and Assessment, 186:47-53, 2013.

SINGH, B.; GILKES, R. J. Concentration of iron oxides from soil clays by $5 \mathrm{~m} \mathrm{NaOH}$ treatment: The complete removal of sodalite and kaolin. Clay Minerals, 26(4):463-472, 1991.

SOMMERS, L. E.; NELSON, D. W. Determination of total phosphorus in soils: A rapid perchloric acid digestion procedure. Soil Science Society of America Journal, 36(6):902-904, 1972.

SOUZA, J. J. L. L. et al. Geochemistry and spatial variability of metal (loid) concentrations in soils of the state of Minas Gerais, Brazil. Science of The Total Environment, 505:338-349, 2015.

UNITED STATE ENVIRONMENT AGENCY - USEPA. SW-846 EPA method 3051A. 1998. Microwave assisted acid digestion of sediments, sludges, soils and oils. In: Test methods for evaluating solid waste, 3rd Update. Washington: US Environmental Protection Agency. Available in: <https:// www.epa.gov/esam/us-epa-method-3051a-microwaveassisted-acid-digestion-sediments-sludges-and-oils>. Access in: September 12, 2019.

THENG, B. K. G. et al. Surface properties of allophane, halloysite, and imogolite. Clays Clay Minerals, 30(2):143-149, 1982.

ZANARDO, A.; MARQUES, J. R. Basic mineralogy concepts. In: MELO, V. F.; ALLEONI, L. R. F. Química e mineralogia do solo Parte I - Conceitos básicos. Viçosa: Sociedade Brasileira de Ciência do Solo, p.89 -95, 2009.

ZÁRUBOVÁ, P. et al. Distribution of $\mathrm{P}, \mathrm{K}, \mathrm{Ca}, \mathrm{Mg}, \mathrm{Cd}, \mathrm{Cu}, \mathrm{Fe}, \mathrm{Mn}$, $\mathrm{Pb}$ and $\mathrm{Zn}$ in wood and bark age classes of willows and poplars used for phytoextraction on soils contaminated by risk elements. Environmental Science and Pollution Research, 22:18801-18813, 2015. 